\title{
ACHILLES’ BRUTISH HELLENISM: GREEK IDENTITY IN THE HERŌIKOS
}

\author{
BENJAMIN MCCLOSKEY
}

$\mathrm{P}$ HILOSTRATUS' HERŌIKOS DEPICTS two anonymous interlocutors who meet and talk. One of the two, known as the Vinedresser, spends much of their conversation informing the other, the Phoenician, about the true history of the heroes, most of which he claims to have learned from Protesilaos. Central to his account are three stories of acts of violence the revenant Achilles commits against humans. This article argues that these acts of violence may be understood as coherent and compatible manifestations of Achilles' cultural identity, which is both violent in its defense of Greece and hostile toward Rome.

Authors of the Second Sophistic were interested, to put it mildly, in defining what it meant to be a Greek. One must add, however, a necessary proviso: a Greek of the Roman empire. The processes of self-definition were polyvalent and could look to the glorious Greek past, the sometimes-glorious Roman present, or both. ${ }^{1}$ This text's two interlocutors, the Vinedresser and the Phoenician, each participate in two different types of Hellenism often discussed in literature of the Second Sophistic.

The Phoenician, despite his name, participates in the culture of the cosmopolitan Greek pepaideumenos, whose behavior is defined primarily through acquired, sophisticated language and culture. ${ }^{2}$ Like Favorinus, he is born a foreigner but performs Greek elite culture by wearing Ionian clothing, speaking Attic, and advertising his classical literary education. ${ }^{3}$ An urbane pepaideumenos, he succinctly characterizes himself by admitting that, although he is so erudite that he recently dreamed he was reading the Iliad (6.3), he stopped believing that heroes were real when he grew up (7.10). ${ }^{4}$ Homer's literary heroes supplanted his belief in genuine heroes.

The Vinedresser, for his part, participates in an archaizing type of Hellenism. This sort of Hellenism, that of the isolated, rural traditionalist, is characterized by a rejection or innocence of the modern world and, sometimes, an inherent

1. See Gleason 1995; Swain 1996; Whitmarsh 2001; Kaldellis 2007; Spawforth 2012. On this process in Philostratus' corpus broadly, see Flinterman 1995; Mestre 2004.

2. See Gleason 1995, esp. 3-54; Swain 1996, 43-56; Whitmarsh 2001, 91-130.

3. See Gleason 1995, 3-20, 131-58; Schmitz 1997, 75-91; Wallace-Hadrill 2008, 3-70.

4. Maclean $(2004,254-56)$ sees him as Greek; Whitmarsh $(2004,240)$ and Mestre $(2004,135)$, as Phoenician; Hodkinson $(2011,24-28)$ sees connections to both.

[C 2017 by The University of Chicago. All rights reserved] 0009-837X/17/11201-0004\$10.00 
paideia. ${ }^{5}$ The Vinedresser, although raised a cosmopolitan Greek, rejected modernity in preference for a spiritual and physical communion with Protesilaos, his handsome and garrulous local revenant (4.6-10). The alleged purity of his Hellenism, facilitated by his rural isolation, recalls Herodes' Herakles or Dio's Euboians. ${ }^{6}$ In contrast to the Phoenician, who does not believe heroes exist, the Vinedresser actually lives with a revenant hero in a friendly, perhaps erotic (10.2-4), cohabitation. The purity that grants the Vinedresser access to Protesilaos grants him access to Protesilaos' memory of real history. The Vinedresser's revelation of this real history to the Phoenician occupies most of the Herōikos, which concludes with his biography of the revenant Achilles.

The Vinedresser's stories about the dead Achilles, including one aside prompted by the Phoenician, comprise the last fifth of the dialogue. Their privileged position as the text's final stories and their unusual content underscore their importance. While their setting on Leuke is derived from Arrian's Periplus, Achilles' actions within this setting are Philostratus' innovation. ${ }^{7}$ The backbone of the Vinedresser's biography of Achilles are his three stories about acts of violence Achilles perpetrates against humans. In the first story, which ranges from the Trojan war to the early third century CE, the Vinedresser explains why Achilles destroyed his homeland, Thessaly. In the second, the Vinedresser describes an incident in which Achilles ripped a woman limb from limb. The third describes how Achilles annihilated an Amazon army. To my knowledge, there has been no prior attempt to understand these three stories as a coherent whole: this will be the focus of my argument.

This article argues that the figure of the dead Achilles, as characterized in the Vinedresser's three stories of his violence, represents an experimental sort of Greek identity. ${ }^{8}$ The dead Achilles commits three acts of violence against humans: (1) against Greeks who threaten Greece; (2) against a symbol of Rome; and (3) against women who dominate men. These actions are not arbitrary but may be understood as manifestations of Achilles' cultural values that are in tension with the practices and beliefs of the Hellenisms represented by the Vinedresser and Phoenician. We must, however, remember the proviso mentioned above: contained within these three stories are clues that allow the reader to detect, as subtext, Achilles' attitude toward Rome. I end by arguing that this text uses Achilles to consider, but reject as problematic, the possibility of violent, cultural resistance to Rome.

\section{ANGER AT GREEK TRAITORS}

The first of the Vinedresser's violent stories recounts the estrangement between Achilles and the Thessalians that results in their destruction. This section is

5. See Whitmarsh 2001, 100-108, esp. 106-7. See also Gleason 1995, 144-45; Swain 1996, 80-87; Whitmarsh 2009b, 211-19.

6. Rusten $(2004,143)$ associates him with Herodes' Herakles; Whitmarsh (2001, 103-5), Rusten (2004, $143), \operatorname{Kim}(2010,181)$, and Hodkinson $(2011,30)$ associate him with Dio's Euboians.

7. Arrian's Periplus Ponti Euxini, in Liddle 2003.

8. As Hodkinson $(2011,28)$ argues, the text as a whole privileges contests over identity and philosophy. On the tension between their identities and beliefs, see Billault 2000, 129-30. 
often understood as a genuine exploration of the history of a cult. ${ }^{9}$ I would, however, rather focus on how Philostratus uses this passage to characterize Achilles. The estrangement between Achilles and Thessaly initially develops along religious lines: the Thessalians repeatedly deny that Achilles is a god. As the relationship develops, however, Thessalian disbelief in Achilles' divinity takes on a political aspect: Thessalian rejections of Achilles necessarily reject panhellenism as well because Achilles is increasingly revealed as the sole divine protector of Greece. The climax of this episode, the destruction of Thessaly, may thus be understood as Achilles' extreme violence in the defense of Greece from traitors to panhellenism. The ending of the story also introduces the question, without answering it, of how Achilles views Rome's relationship with the Greek world. In the beginning, however, Thessaly is respectfully panhellenic.

At first, Thessaly is characterized by internal unity, both political and religious, as well as by panhellenism. All Thessalians happily obey both Protesilaos and Achilles and collaborate with the rest of Greece during the Trojan war (33.22). After the war, the oracle at Dodona demands that all of Thessaly "sail to Troy and burn and slaughter every year to Achilles some offerings as to a

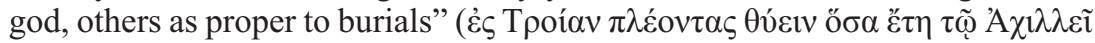

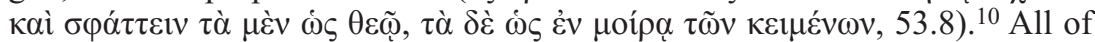
Thessaly obeys. Because it is later revealed that Thessalian cities have religious autonomy, one may retrospectively realize that this passage also shows Thessalian religious unity (53.14). Thus the baseline for Thessalian behavior is unanimous domestic cooperation, panhellenism, and duplex honor to Achilles as dead hero and god.

The first disruption to this unity is religious. So long as the Aiakidai, Achilles' family, rule Thessaly, this happy unanimity persists. The rites to Achilles, however, were later suppressed "by the tyrants who are said to have ruled the

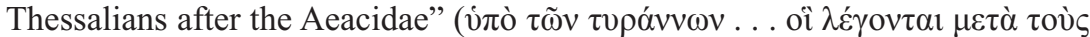

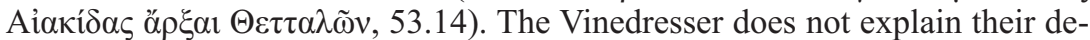
cision. He only notes that some cities abandoned the ritual, that some abandon it but promise to renew it later, and that some even continue it (53.14). This sudden disunity not only reveals that the Thessalian cities have religious autonomy but underscores that they had unanimously decided to honor Achilles previously. The tyrants disrupt the unity of the Thessalians by rejecting Achilles: they must be strongly motivated to so controversially suppress the cult of their civic hero-god. ${ }^{11}$

Examination of the Thessalians' motives suggests political self-interest. Although the Vinedresser does not explain why the rites were suppressed, he make it clear that the rites were suppressed "by the tyrants who ... ruled the Thessalians after the Aeacidae" (53.14). Inasmuch as they are labeled tyrants,

9. See Nagy 2001; Maclean and Aitken 2001; Dué and Nagy 2002; Ondine Pache 2004; Betz 2004; Follet 2004. Burkert $(2004,101)$ and Rusten $(2004,146)$ appear more skeptical.

10. All translations of the Heröikos are from Rusten and König 2014, except when indicated to the contrary. The text is from de Lannoy 1977. On this ritual, see Ondine Pache 2004; Blomart 2004; Betz 2004; Burkert 2004; Grossardt 2006, 713-28

11. Radet $(1925,11)$ notes this as well. Also see Radet 1925, 6; Grossardt 2006, 728. 
they are presented as dynastically unconnected to their predecessors (and, likely, as usurpers). The tyrants underscore their disjuncture with the Aiakidai by making this sharp break with them, as is typical of tyrannies. ${ }^{12}$ We must, however, admit that these tyrants are in a special situation. ${ }^{13}$ Achilles was not merely revered by, but was the preeminent king of, the prior dynasty: he symbolizes them both religiously and politically. By allowing the ritual, the tyrants would annually risk evoking memories in the demos of their predecessors. The annual opportunity to be publicly evaluated against Achilles brings the tyrants risk with no clear reward. Thus, it seems, the tyrants suppress the rite to suppress the memory of Achilles. There is no religious justification for this move - as we shall see, it is criticized by a god - and it is hardly in the interest of Thessaly as a whole, since this Achilles undoubtedly has divine power. It is reasonable to conclude that the tyrants suppress the sacrifice in the interest of their legitimacy. Thus while this first disruption to Thessaly's relationship with Achilles is religious, it appears to be motivated by political self-interest. Such a motive will begin to characterize Thessalian decision-making.

That political self-interest continues to motivate Thessaly's relationship with Achilles can be seen when a drought sends them to an oracle. The oracle com-

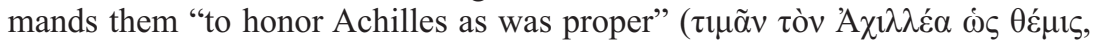
53.15). Thessaly restores the rites to Achilles as dead ancestor but "removed from the performance of the ritual what they practiced for a god (interpreting

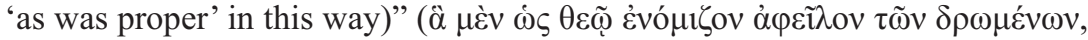

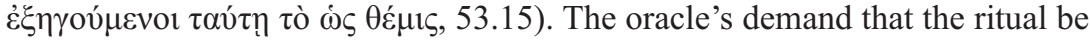
restored must be considered divine criticism of the tyrants, yet Thessaly persists in its disregard for Achilles. Told to honor Achilles as is themis, the Thessalians decide that it is themis to honor him merely as a dead human-not as a god. No individual cities, moreover, are seen to resist dishonoring Achilles any longer. Thessaly publicly and unanimously denies Achilles' godhood, indicating that political self-interest - living tyrants over a dead monarch — continues to drive Thessaly. Their relationship, however, has not yet reached its nadir.

Thessalian self-interest quickly ends this semi-reconciliation when Xerxes invades. The Thessalians unanimously medized and "abandoned once again

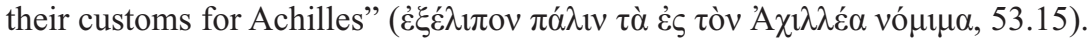
This is because "a ship sailed from Aigina to Salamis, carrying the shrine

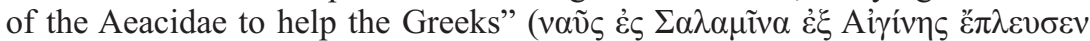

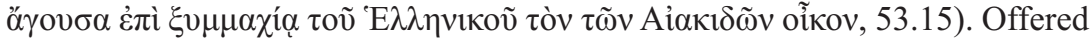
the choice to ally with Xerxes (and the Persians) or with Achilles (and the Greeks), all of Thessaly chooses to abandon Achilles. ${ }^{14}$ Naked political selfinterest drives them. Yet because the Thessalians refuse to ally with Greece, they realize that they can no longer worship Achilles. Achilles, moreover, becomes

12. Radet 1925,9

13. Radet (1925, 9 n. 1) cites Hdt. 5.67 as a parallel example.

14. The Vinedresser omits much of Herodotus: although Herodotus' Xerxes believed the Aleuadai had surrendered for all Thessaly (Hdt. 7.130), many Thessalians resisted (7.172). It was only once the rest of Greece abandoned them (7.173) that Thessaly as a whole medized (7.174). 
sole panhellenic champion: Greece seeks aid from him alone. ${ }^{15}$ Achilles and Greece are now conjoined politically. The Thessalians recognize this, which is why these new enemies of Greece abandon him. They can neither reject Greece without rejecting Achilles nor reject Achilles without rejecting Greece. History will provide them with one last chance to align themselves with Achilles and Greece.

After Alexander's capture of Thessaly there is a moment when the Thessalians seem to finally return to political unity with Achilles. Alexander conquers Thessaly and forces its participation in his expedition (53.16). ${ }^{16}$ At Troy, he declares his alliance with Achilles. For the first time since the Trojan war, the Thessalians find themselves, albeit involuntarily, in a panhellenic army, at Troy, allied with Achilles against Asia. ${ }^{17}$ Indeed, "the Thessalians took an interest in Achilles, and rode around his tomb all the horses which Alexander

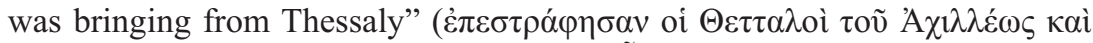

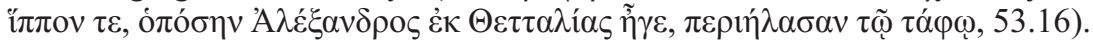
As they depart, they "shouted from their horses for Achilles, with Balius and

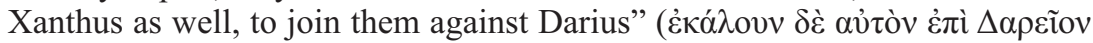

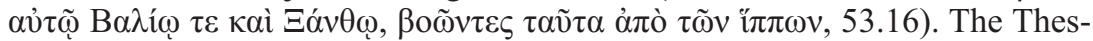
salians underscore their shared love of horses to emphasize their kinship while they request Achilles' help. ${ }^{18}$ In one stroke, Thessaly reunites with Achilles and Greece.

Achilles is, moreover, still the only revenant who aids Greece. Of all those whom Alexander could have invoked, he singles out Achilles. ${ }^{19}$ As during Xerxes' invasion, Achilles is the only revenant who helps Greeks kill foreigners. At this moment, the story of Thessaly and Achilles has come full circle. After Troy, Thessalian self-interest caused centuries of estrangement, but back at Troy they re-accept Achilles as their ally. Unfortunately, they are lying - on account of political self-interest.

The Thessalians do not even wait for Alexander's death to abandon Achilles and panhellenism again. Once Alexander reaches India, "the Thessalians cut

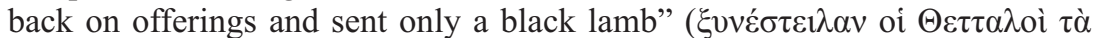

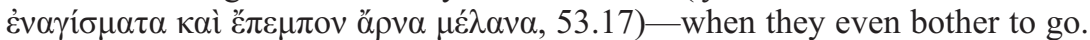
Once Alexander is distracted, they reveal that they had been merely placating him. Even in this - perhaps greatest - moment of panhellenic triumph over foreigners, even when they have no reason whatsoever to reject Achilles, the Thessalians honor Achilles only so long as it pleases their current overlord. Once Alexander crosses the horizon, they instantly and cynically cheapen the ritual, revealing their insincerity. Their pathetic attempt at the minimum - if

15. Philostratus again alters history: in Hdt. 8.64, the Greeks who fetched the Aiakidai invoked Ajax and Telamon, not Achilles. See Grossardt 2006, 729.

16. On Alexander and Achilles, see Betz 2004, 43; Grossardt 2006, 729-30. As Grossardt (2006, 729) points out, it was Philip who subdued Thessaly. Philostratus again alters history.

17. See Spawforth 2006 on Roman attempts to claim Macedonian history; see Swain 1996, 252 on Alexander's flexibility as Greek or Macedonian. As Asirvatham (2006) shows, Second Sophistic authors could also happily distinguish Macedonians from Greeks.

18. See Grossardt 2006, 730 on this ceremony.

19. See Erskine 2001, 228. As Grossardt $(2006,730)$ notes, Alexander also honored Patroklos, Ajax, and Hektor at Troy—another omission favorable to Achilles. 
they can even be bothered to go to Troy, they will not bother to sacrifice correctly - speaks of their profound disbelief in Achilles' divinity. Afraid of Alexander, the Thessalians feign Hellenism and respect for Achilles just as readily as they had rejected both for Xerxes.

The Thessalians have no obvious reason to doubt Achilles: he ends a drought, repulses Xerxes, and crushes Darius. They are urged by two oracles and Alexander to ally with Achilles and Greece. Yet their behavior has been nothing but self-interested: whether shoring up the legitimacy of their tyrants, placating Persia, or placating Macedonia, their religious and political practices are guided only by political expedience. Their attachment to Achilles is as insincere as their attachment to panhellenism. This final insult crosses the line: "Achilles was en-

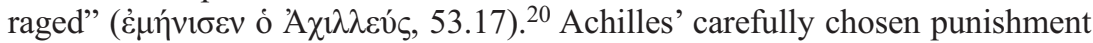
shows that he is well aware that selfishness has driven Thessaly.

Achilles loses his temper in a curious inversion of Iliad Book 1: he asks his mother to harm Thessaly for their disrespect to both himself and Greece. ${ }^{21}$ Achilles has Thetis arrange for Thessaly to be destroyed by Rome in punishment for financial irregularities in its kochlos industry. ${ }^{22}$ The Thessalians' criminal greed has led them to break the law to obtain more of the extremely expensive commodity than is due to them (53.22). As a result of the Romans' punishment,

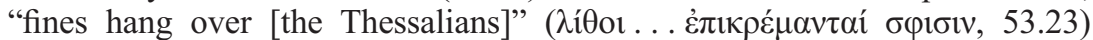
which compel the sale of their homes, fields, and slaves. ${ }^{23}$ Finally, "many do not perform funeral offerings to their parents; for they had to sell even their tombs"

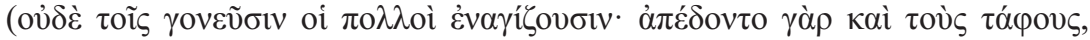
53.23). Achilles is well aware of what motivates the Thessalians. They have repeatedly sided with foreigners out of self-interest, so he arranges for foreigners to destroy Thessaly by punishing them for criminal self-interest. This last act of Thessalian selfishness is punished by the loss of all they had selfishly increased: their houses, fields, and slaves. Achilles also pointedly strips them of their ancestors' tombs. Since they will not honor him at his, they lose the tombs of all other ancestors. ${ }^{24}$ Thessaly has earned its destruction, at least in Achilles' mind.

Achilles so loses patience with his own people that he destroys them. Although this passage purports to only address the hymns of the Thessalian ritual at Achilles' tomb (52.3), we can see that it goes far beyond its remit. It reveals that Achilles, the sole divine protector of Greeks, chooses an apropos annihilation for Greeks who offended him religiously and politically.

In certain ways, this Achilles is conventional. Like his peers, he inhabits his tomb, helps his friends, and hurts his enemies. Yet, unlike his peers, who spend most of their time aimlessly haunting the Troad, Achilles repeatedly intervenes

20. Philostratus' Vita Apollonii presents either the same story, as Rusten and König $(2014,39)$ suggest, or a variant. In the $V A$, Achilles asks Apollonius to convince Thessaly to resume its rite to him (4.16), which he does (4.23). This is incompatible with (or ignores) the Herōikos, which attributes the contemporary destruction of Thessaly to a crime in the time of Alexander.

21. Curiously, the Herōikos has already rejected the historicity of Iliad Book 1: see 25.16 and 33.34-36.

22. On kochlos, see Reinhold 1970; Edmonds 2000; Bradley 2009.

23. Maclean and Aitken $(2001,163$ n. 187) and Grossardt $(2006,734)$ point to Huvelin's analysis, appended by Radet to his own article $(1925,18-20)$, that Roman tax liens were imposed on Thessaly. On the perhaps related nationalization of the kochlos industry, see Reinhold 1970, 58; Maclean and Aitken 2002, lxxii.

24. Grossardt $(2006,735)$ also notes how apt this punishment is. 
in the political trajectory of Greece. What causes him to stand out even further, however, is his hard-line stance. Other revenants, as we will see below, grow angry at individuals; Achilles, however, is enraged by political and religious disagreements on an ethnic level. Other angry revenants kill individuals; Achilles, in his rage, destroys his homeland. Achilles becomes something akin to the political officer of Hellenism: the less panhellenism Greeks display, the more they risk annihilation. Achilles ultimately rejects negotiation in favor of unilateral violence. ${ }^{25}$ This first story of violence characterizes Achilles as the sole panhellenic champion who destroys anyone domestic or foreign who threatens Greece.

A certain dissonance is, however, introduced at the end of this story: Achilles defends Greece from foreigners but uses Rome to destroy Thessaly. I would suggest that this dissonance - which remains unresolved for now-subtly problematizes where Rome rests on the spectrum ranging from Greek to not-Greek. In Achilles' mind, are the Romans: (1) Greeks; (2) less non-Greek than the Thessalians; (3) acceptable non-Greeks; or, (4) the tool of the moment? The reader may consider how this violent, panhellenic Achilles thinks of Rome but cannot yet hazard an answer. We may thus proceed with Rome in the back of our minds to the second story of Achilles' violence.

\section{ANGER AT ROME}

As this episode ends, an interruption by the Phoenician diverts the Vinedresser onto a lengthy description of the revenant Achilles' lifestyle and poetry. ${ }^{26}$ After he has satisfied the Phoenician, he returns to his second story of violence, which narrates Achilles' killing of a slave. In analyzing this section, I make three arguments that build off one another. First, Achilles' motivation in killing the slave is concealed by Achilles and omitted by the Vinedresser. Since the meaning of this episode hinges upon Achilles' motivation, and since the Vinedresser has already criticized Homer for suppressing scandals through omission, I argue that the text problematizes the interpretation of this killing. Second, the modern interpretation of Achilles' motive- lingering resentment over his death - is not supported by the text. Third, the reader may use textual clues to discover anger at Rome behind Achilles' violence.

The Vinedresser briefly recounts Achilles' killing of a Trojan slave (56.1-10). After befriending a merchant who stopped on Leuke, Achilles asks him to go to Troy to buy a particular slave. Achilles says he wants her "Because ... she is from the same line as Hector and his ancestors and is the last of the blood

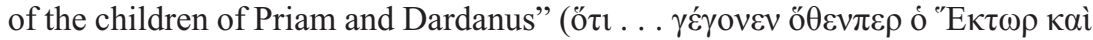

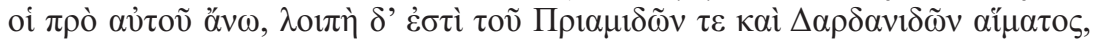
56.7). When the merchant, believing that Achilles is in love, brings her to Leuke, Achilles insists she stay on the boat until the merchant departs. As the

25. Contrast the Vinedresser and Phoenician's negotiation of their cultural differences which underlies most of their conversation. See Hodkinson 2011, esp. 24-25.

26. Since Her. 54.1-55.6 results from the Phoenician's spontaneous question, it cannot have been part of the stories of Achilles' violence that the Vinedresser intended to tell (and which this article focuses on). It has been well discussed by Miles (2005), who emphasizes Achilles' poetic and musical side, which is not apparent in these three stories of violence. See also Kim 2010, 212-13. 
merchant and his crew sail away, "They were not more than a stade away from shore, when the girl's scream reached them-Achilles was tearing her

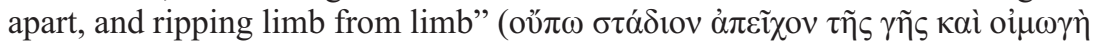

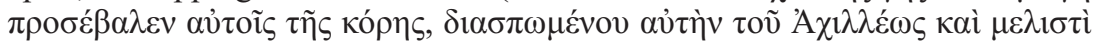

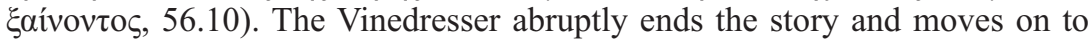
the last story of Achilles' violence. As scholars have realized, there is a major interpretive problem with this passage: why does Achilles kill this woman and why in this way? Two provocative omissions in this passage conceal Achilles' motive in killing the woman.

The first omission is that Achilles does not tell the merchant why he wants the woman. When Achilles asks the merchant to go buy her, the merchant asks him the obvious question: why does he want her? Achilles' response is that she is the last member of the Trojan royal family (56.7). This explains who the woman is but not why he wants her. The merchant is aware that this answer is inadequate: as he leaves he interprets what he thinks Achilles means: "The merchant thought that Achilles was in love, so he bought the girl" ( $\dot{o} \mu \dot{\varepsilon} v$

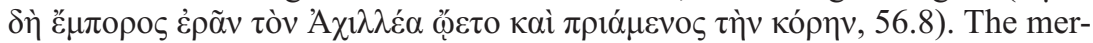
chant, treating Achilles' mysterious statement as oracular in its opacity, interprets his words as signifying erōs. If he is thinking of Polyxena, the slave's death at Achilles' hands quashes his reading. ${ }^{27}$ This takes us to the second omission: the Vinedresser's.

The Vinedresser abruptly ends the story without explaining, much less justifying, the killing. Yet the Vinedresser has revealed himself to be effectively omniscient about Achilles. Not only has he memorized Achilles' poetry (55.3), but he knows the details of Achilles' marriage with Helen (54.12), his emotions (53.17), and things Achilles has done that no human witness survives (57.12-17). Because the Vinedresser knows everything else about Achilles, the reader has every reason to believe that he also knows his motivation, yet he does not reveal it. In light of the Vinedresser's earlier attack on Homer, this omission is provocative.

The Vinedresser's omission in this passage plays with his earlier criticism of Homer. He had attacked Homer on the grounds that he "knew the truth, but changed much of it to benefit the subject he had chosen" ( $\tau \dot{\alpha} \dot{\alpha} \lambda \eta \theta \tilde{\eta} \mu \dot{\varepsilon} v \varepsilon \tilde{\varepsilon} \mu \alpha \theta \varepsilon$,

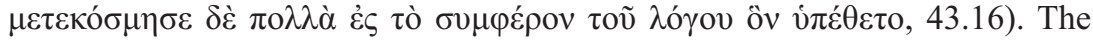
dead Odysseus told Homer the truth about Troy on the condition that he depict Odysseus sympathetically by suppressing his murder of Palamedes (43.15). According to the Vinedresser, Homer's poetry is dishonest - and in need of correction - as a result. Yet the lynchpin of the Vinedresser's story of violence is Achilles' motive in killing the woman: if the reader cannot understand this, the entire episode remains meaningless. This is to say, the Vinedresser's crucial omission of Achilles' motive in killing the slave-in light of his earlier attack on Homer's own omissions - may encourage the reader, piqued, to consider whether the Vinedresser is suppressing his own scandal. ${ }^{28}$

27. Grossardt $(2006,753)$ sees parallels between this story and Polyxena

28. The interpretive challenge offered to the reader by this passage recalls the general interpretive playfulness of the Heroikos, as Hodkinson (2011) has persuasively argued. 
Scholars have indeed been piqued by this scene. Graham Anderson labels the killing as "bizarre" and "un-Hellenic," while Andreas Beschorner speaks of the "überraschendes Ende" of the passage. ${ }^{29}$ The killing is troubling because it is neither justified nor even explained. If Achilles' motive can be understood, does it support his positive portrayal in this text or is the Vinedresser participating in his own cover-up? Several scholars, including Anderson, have suggested that Achilles' motive is revenge: he kills the last Dardanid to avenge his own death during the Trojan war. ${ }^{30}$ While this is plausible, I would argue that the text does not support this.

One objection is that, unlike many of his colleagues, the dead Achilles is a model of reconciliation compared to his peers. For example, Ajax is still so hateful that the earth around his tomb is thronged with plants that sicken Trojans (18.3). His most memorable moment after death is when he gets into a screaming match with local drunks about the Trojan war (18.4-5). Hektor, in turn, kills an Assyrian for insulting his service in the Trojan war (19.5-7). Even as revenants their egos remain unhappily intertwined with the war. Achilles, however, has moved on: he regularly holidays at his Trojan tomb. While there, he "visits and holds conversations with a few people and hunts wild

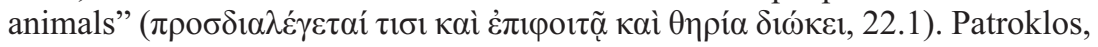
who lives year-round at Troy in Achilles' tomb, even prevents the murder of a Trojan shepherd (22.3). He could have enjoyed the frisson of the death of a Trojan but prevents it. This relaxed attitude toward Trojans shared by Achilles and Patroklos is incompatible with an analysis that attributes his motivation to bitterness. Achilles, in the revisionist atmosphere of the Heroikos, loses his traditional hostility toward Trojans - contrast the revenant Achilles' implacable hatred of Trojans explicitly linked to his death in Philostratus Life of Apollonius 4.12 .

Not only is the reading that Achilles killed the slave because of her connection with the Trojan war inconsistent with his general behavior, but it is also incompatible with how he bungles his plot. Achilles' careful preparations signal that he wanted the killing to be a secret. He discreetly singles out and befriends a devotee capable of procuring this woman (56.6). He quickly indebts him so, it seems, he can exploit him for this favor (56.6). When pressed for his motive, his answer is vague and misleading (56.6). Once the slave arrives, he avoids meeting her in the presence of the merchant, avoiding the need to dissemble (56.7). By singling out and lavishing a devotee with attention, Achilles ensures that he will get his victim-discreetly. ${ }^{31}$

Everything Achilles has done up to this point has worked to conceal the killing, yet he spoils his plans at the last moment. As the merchant sails away, he hears her scream: he is still within earshot (56.10). Anderson argues that the merchant hears her because "[s]uch an incident has to be provided with a witness." 32 This is unpersuasive. This text almost entirely derives its authority

29. Anderson 1986, 246; Beschorner 1999, 208.

30. Anderson 1986, 246-47; Maclean and Aitken 2001, lix.

31. Achilles' plot recalls his murder of the prisoners in the Iliad. See Richardson 1993, 187 on Achilles' premeditation of, and Hughes 2007, 16 on the later reception of this killing.

32. Anderson 1986, 247. 
from the (effective) omniscience of Protesilaos: this makes Philostratus' switch to a human witness significant. ${ }^{33}$ Had Philostratus need of a witness for the sake of a witness alone, Protesilaos would have been both obvious and better. Compared to Protesilaos, the merchant disappoints: his human senses prevent him from witnessing much. Yet inasmuch as he is the witness, it is precisely his human perspective that distinguishes him from Protesilaos. By showing the killing through his eyes, Philostratus subtly bounds its chronology in a way he could not have if he had used (the omniscient) Protesilaos. The killing occurs after the merchant casts off but before he sailed one stade, or six hundred feet: only a few minutes have passed. The merchant's humanity reveals Achilles' failure to restrain himself for even the short time necessary for the merchant to leave earshot. This suggests that the killing is explosively passionate.

Yet it is precisely this passion that suggests Achilles is not angry about his death. Achilles is calm enough to plot the slave's death, yet he loses control once he sees her. Yet Achilles regularly vacations at Troy (22.1). The slave herself lived at Troy. Achilles has, thus, spent many days, weeks, or monthshowever long he stays each year - as neighbor to this last Dardanid (and all her ancestors) and yet, on each visit to Troy, he leaves her (and left them) alone. Yet when he meets her on his beach, he cannot stop from almost instantly dismembering her live. It seems that something new has caused Achilles to coolly plan her secret killing and yet to lose control once he sees her. All of these points, taken together, suggest that his anger must be traced back to a stimulus other than his death.

Achilles kills the woman not because of her association with the Trojan war, but nevertheless because she is the last member of the Trojan royal family. I would argue that the text makes certain clues available to the curious reader that allow a different analysis. Aspects of Achilles' behavior can, alongside the probable dramatic date of this passage, point to another motivation behind the killing.

If we compare this scene to similar moments, we may see that the woman did nothing to upset Achilles. Protesilaos punishes two adulterers who plot crimes at his shrine (16.3-4); Ajax punishes shepherds who insult him at his tomb (18.4-5); Hektor punishes an Assyrian who abuses his statue to its face (18.6); Achilles will himself punish crimes committed on Leuke (56.11-57.17). These moments share two relevant qualities. Revenants punish humans in response to specific offenses; second, the crimes that revenants typically punish are committed at their places of power. The Trojan slave, however, is not seen to act, much less against Achilles, much less at one of his places of power. One can conclude that Achilles does not target her because of anything she has done. While I agree with Anderson's argument that Achilles kills her symbolically, I disagree that he does so to avenge his death. In what follows, I argue that it is her connection to Rome that triggers the violence.

If we understand how Achilles views her, we may understand why he kills her. He describes her as "from the same line as Hector and his ancestors and is the last of the blood of the children of Priam and Dardanus" (ö $\theta \varepsilon v \pi \varepsilon \rho$ o

33. As Maclean and Aitken (2001, lxxiii) point out, the Vinedresser has in fact been speaking on his own authority throughout the Thessalian story. See Billault 2000, 129 on Protesilaos' omniscience. 


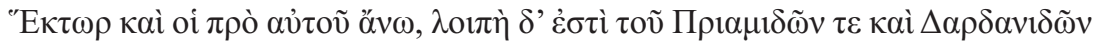
$\alpha i \mu \alpha \tau o \varsigma, 56.7)$. He is thinking about her in genealogical terms. Her genealogy once led him to leave her (and her family) alone but now leads him to kill her (to exterminate her family). Some change in regard to her family, but outside the woman herself, prompts Achilles to view her ancestry, previously innocuous, as a capital crime.

Two further clues may help reconstruct why Achilles targeted this slave: his desire to keep the killing secret and the dramatic date of this passage. Revenants elsewhere in this text make no attempt to harm humans in secret. Ajax et al., including Achilles himself, harm publicly. ${ }^{34}$ Yet Achilles tries to conceal this killing. This is not only abnormal for revenants but for Achilles himself. What motivates his secrecy? One might ask: why does anyone kill secretly? Two answers suggest themselves: shame or fear of the consequences. Shame is not, however, persuasive. First, Achilles has publicly murdered innocents before. The Trojan prisoners, after Patroklos' death, allowed him to symbolically harm Troy. ${ }^{35}$ Even if he had killed this slave in secret, it would have hidden nothing from the gods. What shame would he feel before humanity but not before Zeus or his mother? Shame is not persuasive.

If shame rings false, this suggests that Achilles may be concerned about the consequences. Yet he has purchased her. Her family, the Dardanids, is dead. The Trojans, who let her be a slave, surely do not care. If no human cares about this slave and if Achilles does not care about the reaction of the gods, whose reaction is he concerned about? The second clue, the dating of this story, suggests an answer.

Of the three stories of Achilles' violence told by the Vinedresser, only this story is not given an explicit date. The two clues internal to the story only suggest a vague posteriority: Helen is dead and only one Dardanid still lives. Is this a century or a millennium after the war? If we look outside this story itself, however, we find a better hint.

The structure of the Vinedresser's stories suggests a more specific date. His first story, as we saw above, passes through the whole of history to end in the present day, the early third century CE. The Vinedresser then passes to the chronologically vague episode of the slave. The final episode, that of Achilles and the Amazons, is precisely dated: it occurs at the time of the Olympics in which Leonidas of Rhodes, the famous athlete, won his first victory (56.11). Any sports fan, such as Philostratus, could date this to the first year of the 154th Olympiad, 164 BCE. ${ }^{36}$

In the absence of any other data, the sandwiching of this story between these other two bounds this story both in the mind of the Vinedresser and on the page between the third century CE and $164 \mathrm{BCE}$. If this story occurs between these two dates, between now and 164 BCE, the trajectory of the Vinedresser's narrative of Achilles' anger may be seen to move across the three stories from the Trojan war to the present and then back into the past. But, more significantly,

34. Ajax: 18.3-4; Protesilaos: 16.3-4; Hektor: 18.6, 19.5-9.

35. Il. 23.175-76. See Richardson 1993, 189 on Achilles' extreme violence in this passage.

36. See Gymnasticus 33, in Rusten and König 2014, for the other mention of Leonidas by Philostratus. 
the story of Achilles' killing of the Trojan is bound by two stories that themselves bound Rome's dominion of Greece. The Olympics of 164 BCE is the first after the dissolution of the Antigonid state and the first permanent loss of Greek sovereignty to Rome. ${ }^{37}$ They are the first Olympics of Roman Greece.

These clues help clarify the interpretative challenge of this passage. Achilles targets the slave due to her genealogy. He tries to conceal the killing from humans but not gods, which suggests that he is worried about consequences in the human realm. This story is bookended by two others, themselves dated to the early third century CE and 164 BCE. If, as I have argued, Achilles has not killed the woman because of her connection to the Trojan war, the reader should return to the text for clues to another answer. All these clues point to the slave's connection to Rome as the source of Achilles' anger.

Long before Virgil, Romans were linked to their sometimes-ancestors, the Trojans. ${ }^{38}$ Both the Greeks and Romans found that forging mythological ties between Rome and Greece via Troy could be useful. ${ }^{39}$ The Romans could use the association to justify their presence in the East, as Scipio did, or to encourage rapprochement with Greece, as the Julio-Claudians did. ${ }^{40}$ Inasmuch as she is Trojan, the slave contains a potential association with Rome; inasmuch as she is a Dardanid, she is potentially linked even more closely to Rome and Augustus' empire via Aeneas. There is at least a potential link between the slave and Rome on account of her genealogy.

Achilles' violence is best explained if he sees her as symbolic of Rome. First, the timing of this episode begins to make sense. The later this killing occurs - especially after $164 \mathrm{BCE}$ - the less credible the connection of Achilles' death to his explosive passion. Moreover, that it occurs after 164 BCE puts it firmly in the period in which Rome began to dominate Greece. As the first episode showed, long before 164 BCE Achilles had established himself as sole defender of Greece. This is not revenge for his death, but revenge for Rome's conquest of Greece. Achilles takes such a hard line against the Thessalians for their insufficient commitment to panhellenism that he destroys them. There is no reason to expect that he would welcome Rome's conquest of Greece with open arms: in fact, his rending of the woman limb from limb may mimic Rome's piecemeal conquest of the Greek world.

The question of why Achilles would attempt to conceal this killing had been puzzling. He did not try to conceal what he did from the gods, yet this orphaned slave had no human protectors. His actions begin to make more sense, however, if he killed her because of her connection to Rome. Achilles' attempt at secrecy is best explained if he wanted to express his anger against the Roman state but wanted to avoid drawing the ire of Rome to his Greeks. ${ }^{41}$ That he foiled his own plot speaks to how enraged he was.

37. Gruen $(1982,257-58)$ argues that Polybius in particular created the perception that the settlement of the Third Macedonian War initiated Rome's dominion of Greece.

38. See Gruen 1992, 6-51 and Erskine 2001 on the process by which Rome becomes associated with Troy. As Gruen $(1992,10)$ notes, this process was largely initiated by Greeks.

39. See Bremmer and Horsfall 1987, 21; Toll 1997, 42.

40. See Erskine $2001,234-36$ on Scipio and $17-23$ and $245-54$ on the Julio-Claudians.

41. See Whitmarsh 2009a, 119 and Flinterman 1995, 47-48 on the dangers of hostility to Rome. 
It is here that our two strands most closely intertwine: Achilles is interested in the woman's ties to Rome. This episode deepens our understanding of Achilles. Although in the first episode he abandoned dialogue for unilateral violence, he becomes more monstrous here. Achilles ignores dialogue this time: his first recourse is brutal violence on dubious grounds of culpability.

The first episode introduced the question of Rome and the second resoundingly answered it. Though he uses Rome, Achilles despises Rome. Given that Achilles always acts to defend Greece and that he hates Rome, one might wonder: why did Achilles not intervene to save Greece from Rome as he had from Xerxes? This, I argue, is answered in the final episode.

\section{Anger at Women Who Dominate Men}

When the Vinedresser ends the story of the slave, he abruptly changes topics and, without explanation, begins his third story about how Achilles killed some Amazons. In this story, shipwrecked merchants provoke an Amazon invasion of Leuke, whereupon Achilles kills everyone involved. Using Homer's Odyssey and Herodotus as points of comparison, I argue not only that both the merchants and the Amazons violate traditional gender roles, but that Achilles punishes this violation. The story begins with the merchants.

The Vinedresser only minimally characterizes the merchants. He says that they are "sailors and shipbuilders" who trade between the Pontus and the Hellespont (57.8). ${ }^{42}$ He does not reveal whether they are Greeks, Hellenized, or neither. Given that these merchants trade between the Pontus and the Hellespont in the second century BCE, and given that they are modeled on Greeks in an episode of Herodotus I discuss below, they are likely Hellenized, perhaps Greeks. ${ }^{43}$ Whatever their cultural identity, however, their salient quality is their (lack of) masculinity.

They shipwreck among the Amazons. Washing ashore, "They were captured by [the Amazons], bound, and fattened up at mangers for some time, so that they could . . . sell them to Scythian cannibals" ( $\lambda \eta \varphi \theta \varepsilon \dot{\varepsilon} v \tau \varepsilon \varsigma \delta \dot{\varepsilon}$ vं $\pi$ ' $\alpha \dot{\tau} \tau \tilde{\omega} v$

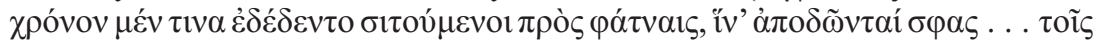
$\dot{\alpha} v \delta \rho \circ \varphi \alpha ́ \gamma o 1 \varsigma \Sigma \kappa v \theta \alpha 1 \varsigma, 57.9) .{ }^{44}$ The merchants await the next cannibal market perched between the genres of history and epic. ${ }^{45}$ Reference to both the Odyssey and Herodotus reveals how far they fall short of normative Hellenic masculinity.

The merchants' arrival in the Amazons' land alludes to both Odysseus' arrival in Scheria and Herodotus' Greek invasion of the Amazons. ${ }^{46}$ Shipwrecked,

42. See Magie 1950, 178-79 on the booming economy of the Pontus in this period.

43. The region of Pontus, and even Colchis to its east, was Hellenized before the second century BCE. Braund $(1994,132)$ argues that as early as the fifth century there was "some form of symbiosis" between Greeks and costal Colchians, that in the fourth century "Greek influence becomes very apparent" (p. 136), and that by the end of the fourth century Greek language was common in a larger city like Vani which may have even been experimenting with Greek-style government (p. 137).

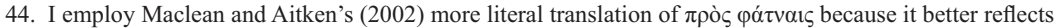
the barnyard setting of their imprisonment.

45. While the Odyssey's various cannibals leap to mind, Hdt. 4.106 does locate cannibals in Scythia.

46. Grossardt $(2006,763)$ also argues that this passage is based on Hdt. 4.110-17. I would like to thank both of $C P$ 's readers for encouraging me to expand my discussion of Herodotus in this passage. 
both Odysseus and the merchants wash ashore to be confronted by women who threaten their homecoming. Odysseus encounters Nausicaa and Arete, who endanger his homecoming with the threat of marriage. ${ }^{47}$ The merchants also recall Herodotus' Greek invasion of Amazonia: the Greeks defeat the Amazons at the Thermodon and load three boats full of prisoners (4.110). The Vinedresser's merchants come off poorly in both comparisons. Unlike Odysseus, they are neither resourceful nor divinely favored enough to obtain hospitality; unlike Herodotus' Greeks, they are conquered and imprisoned by the Amazons.

Their imprisonment by the Amazons recalls both Circe's and Herodotus' Greeks' imprisonment of the Amazons. The merchants are captured and "fat-

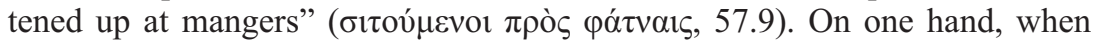
the merchants and Odysseus' crew are captured by women, both groups are transformed into animals: Circe literally transforms her prisoners into animals, tossing their food into the pigsty while the merchants feed from mangers like animals (Od. 10.236-43). Yet the merchants have no Odysseus (or divine favor) to save them. Herodotus is also inverted: his Greeks capture the Amazons, not the other way around (4.110). These merchants appear unheroic and passive.

The merchants' passivity is most noticeable in regard to their sexuality. Odysseus conquers Circe by having sex with her on his terms: his domination of her is incomplete until it is sexual (10.345-47). ${ }^{48}$ Although Herodotus does not explain why his Greeks captured the Amazons, enslavement and sex are likely key. ${ }^{49}$ Thus Herodotus' Greeks likely anticipate sex with their new slaves and Odysseus sexually dominates Circe. As the merchants passively await death huddled in the barnyard, however, they become the target of the sexual gaze of the Amazons.

One Amazon princess grows aroused while watching them. The Vinedresser says, "But when one of the Amazons took pity on a young man captured with

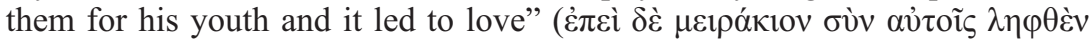

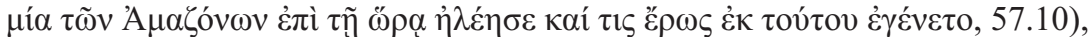
she obtains clemency from the queen. ${ }^{50}$ The Greeks are freed, but shamefully: a man passively arousing the active woman inverts normative gender roles. ${ }^{51}$ Contrast Herodotus: once the Amazons land in Scythia, they are defeated by the Scythians (4.111) who then surround their camp (4.111-13). Yet even defeated and besieged, the independent masculinity of these Amazons is clear: they negotiate as equals about their impending sexual relationships with the Scythians (4.113). ${ }^{52}$ Each Amazon decides which Scythian man she wants (4.113) ${ }^{53} \mathrm{In}$

47. See Ahl and Roisman 1996, 49-60 on Nausicaa and 66-67 on Arete.

48. Per Ahl and Roisman (1996, 123), Odysseus must resolve Circe's threat to effeminize him before he can have sex with her. See Hermes' warning to Odysseus at $O d$. 10.297-301.

49. Herodotus focuses on how the sexual and marital relationships develop between the Amazons and the Scythians rather than between the Amazons and the Greeks (whom the Amazons kill). The parallel suggests that the Amazons replace (potential) Greek lovers with (actual) Scythian lovers.

50. As one of $C P$ 's readers has helpfully pointed out to me, twice elsewhere in Philostratus a $\mu \varepsilon 1 p \alpha ́$ кııv is preyed upon by sexual predators, by Timasion ( $V A 6.3)$ and by Domitian $(V A 7.42)$.

51. Gleason 1995, 62-65, 79. Grossardt $(2006,764)$ sees an allusion to Hypermestra and Lynceus.

52. See Corcella 2007, 658-59 on the historical Sauromatians' involvement in myth with the Amazons.

53. Notice, however, that there is not perfect equality. Hdt. 4.111 makes it clear that it was the Scythians' unilateral decision that there would be relationships at all. The Amazons are able to select their partners but not to choose whether they want partners in the first place. 
contrast, Philostratus' Amazons unilaterally decide that, because their princess is aroused by a merchant, there will be a sexual relationship between the two groups. These merchants are not treated as equals, however: they are dragged out of the prison for sex without any negotiation. The power differential between the merchants and Amazons not only clashes with the relative equality between Herodotus' Scythians and Amazons, but these merchants, by being treated like — and acting like_-passive sexual objects, show less masculinity than either group of Amazons. ${ }^{54}$

Once the merchants are freed, they immediately reveal themselves as more effeminate still. The Vinedresser says, "After the sailors were released and

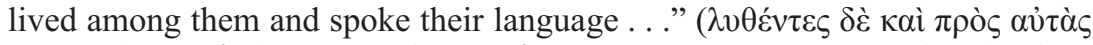

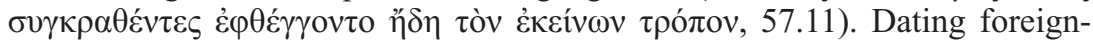
ers, the merchants are faced with the inevitable choice: learn their language or teach them their own. Unlike the Scythians, who fail to learn Amazonian (4.114), these merchants do learn it. There is, however, a crucial difference visà-vis the situation in Herodotus. The merchants' and the Scythians' decision to learn Amazonian suggests a certain subservience. For the Scythians, however, it must be weighed against their victory over the Amazons; for the merchants, it can only be weighed against their defeat. The merchants' decision to learn Amazonian after their defeat emphasizes the masculine Amazons' dominance of these relationships in a way that the Scythians' similar decision does not. While the merchants may be smarter than the Scythians, they are less masculine. Yet their decision has even further problematic implications.

In the Second Sophistic, discussions of language were deeply politicized: choices of Greek over Latin and of Attic over demotic were at the heart of the debate over one's cultural identity. As Tim Whitmarsh puts it, "cultured Hellenism . . . distilled into Atticism . . . is defined by opposition to brutal barbarism." 55 One's identity is fundamentally linked to language: while this allows foreigners to become Greek, it also implies that Greeks who stop speaking Greek stop being Greek. ${ }^{56}$ Whatever the merchants' native language, the rapidity and ease with which they abandon it suggests that they have, in some sense, equally easily become male Amazons - a new, anomalous gender in an already anomalously gendered society. Their commitment to their language (and thus culture) is as weak as their commitment to their gender. While Herodotus' Amazons join their Scythian equals to become the Sauromatians, the merchants are subsumed into the Amazons.

By learning Amazonian, the merchants gain one final opportunity to obtain even a modicum of control over their lives with the Amazons. Contrast Herodotus' Amazons: after they learn Scythian, they and the Scythians negotiate as more or less equals about where they will live and which lifestyle they will follow (4.114-16). When the merchants finally speak to the Amazons,

54. Note, as Corcella $(2007,660)$ argues, that the relative equality of the relationship between the Scythian men and Amazons itself subverts Greek gender norms. That Philostratus' merchants fall so short of the masculinity of the dubiously masculine Scythians is telling.

55. Whitmarsh 2009b, 215; also see Schmitz 1997, 148; Gruen 2006; Follet 1991, 207-8. See Swain 1996 , 56-64 and Whitmarsh 2009a, 116-20 regarding Hellenisms focalized elsewhere than Atticism.

56. See Flinterman 1995, 90-91. 
however, there is no negotiation. Introducing themselves for the first time, the merchants happen to mention the wealth of Achilles' shrine on Leuke (53.11). The Amazons realize they could reach Achilles with the aid of their merchants. The Vinedresser says, "And the women, considering the strangers a lucky find since they were sailors and shipbuilders, and since their land was conducive to building ships, constructed ships for horse transport to seize Achilles on

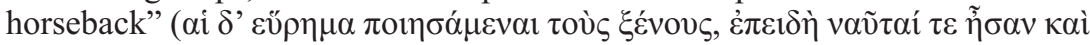

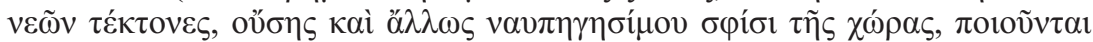

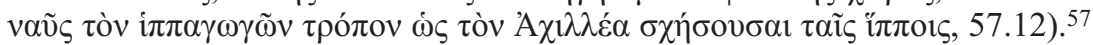
In contrast to Herodotus, what is important is what is not done. These Amazons do not negotiate with the merchants: once the merchants mention Achilles, they lose their agency. The Amazons marshal their resources - the shipbuildermerchants and Amazonia's trees are mentioned as if equally two of their

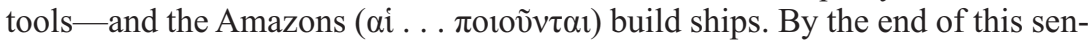
tence, the merchants are subsumed into " $\alpha i$." Shipwrecked among the Amazons as independent men, by the end they are lumped into the feminine "ai" of their sexually dominant masters who treat them as slaves. No new ethnos, like the Sauromatians, is created by their union: the merchants are so passive they are absorbed by their Amazonian masters.

These Amazons, moreover, are broadly conventional with one significant innovation: the Vinedresser's etymology of their name. The traditional etymology is linked to their excision of one breast. ${ }^{58}$ These Amazons, however, are typical mothers "except for withholding their milk; this they do because of their warfare,

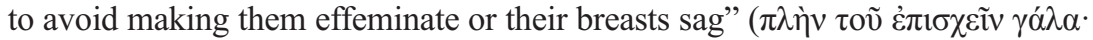

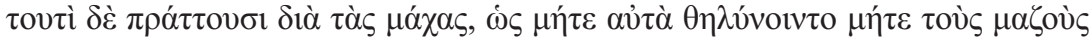
$\dot{\alpha} \pi о \kappa \rho \varepsilon \mu \tilde{\omega} \nu \tau о, 57.5)$. The Amazons believe in Greek gender theory. They raise their daughters on mares' milk to prevent the effeminization caused by human milk. ${ }^{59}$ The Amazons' masculinity is not innate but deliberately constructed.

These Amazons, knowing that their femininity would normally subordinate them to men, attempt to raise masculine daughters by substituting (allegedly effeminizing) mothers' milk with (allegedly masculinizing) mares' milk. Adult Amazons ride the same, masculinizing, mares into battle. Only the latter stratagem succeeds. The Vinedresser notes that "Dismounted from their mares,

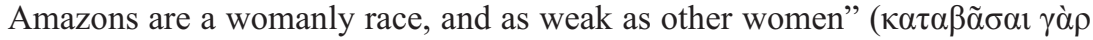

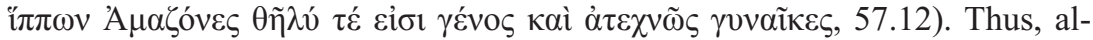
though Amazon pedagogy fails to extirpate their femininity, when mounted they are able to become temporarily unfeminine. Their ability to transcend their femininity is linked solely to their horses.

57. I have adapted Rusten and König's ". . . to attack Achilles on horseback." While both "attack" and "seize" are potential readings of $\varepsilon \chi \omega$, the key is in the next sentence: "Dismounted from their mares, Amazons are . . . as weak as other women.” This explains something in the prior sentence. In Rusten and König's translation, it explains why they attack on horseback: they are weak on foot. My reading, however, also implies why they intend to attack Achilles, which the text never addresses. The Amazons want to put Achilles out to stud to perhaps attain a permanent masculinity via his paternity. The invasion is an act of female sexual aggression, which further explains the threat these women pose. On the advice of one of $C P$ 's readers, I have also altered Rusten and König's translation of the first words of this: "When the women learned about this from their guests."

58. For general discussion of Amazons, see Cantarella 1987, 16-18; Blok 1995; Bremmer 2000

59. See Gleason 1995, 58-59. 
These mounted, and thus masculine, Amazons threaten men: they attack Achilles and, by extension, all the Greeks he defends. Their invasion threatens to subdue Greek men to Eastern women. ${ }^{60}$ They have readily effeminized all men they have encountered - but they have not yet met a man like Achilles.

When the Amazons land on Leuke, the punishments that Achilles chooses for the merchants and Amazons reveal his thoughts about both groups. When the Amazons, Erysichthon-like, command the merchants to chop down Achilles' sacred grove, Achilles massacres the merchants with their own axes (57.13-14). ${ }^{61}$ A straightforward punishment: they tried to hurt him with their axes, so he kills them with the same axes. He reserves his fury for the Amazons. Achilles, as always, picks a pointed form of retribution. Just as he used foreigners to kill the Thessalians and the merchants' axes to kill the merchants, so too he now turns the Amazons' means of offending him against them. He terrifies their horses and "cast on the mares a terror stronger than any bridle,

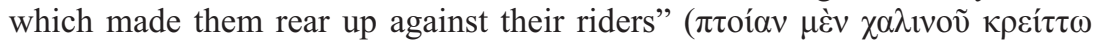

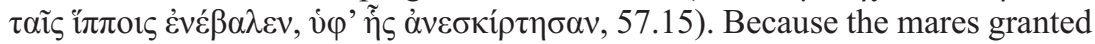
the Amazons sufficient masculinity to threaten Achilles, he uses the mares to kill them. He turns the horses into misogynists: they suddenly see the Amazons

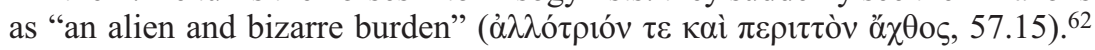
The horses throw their riders and eat them live (57.15). The horrifically unnatural transformation of domesticated horses into anthropophages is, in Achilles' mind, suitable punishment for the Amazons' crimes against nature. Achilles sees the Amazons as an abhorrent threat to masculinity and, as usual, he turns their means of transgression against them. Achilles brutally restores the patriarchy. His resolution of this story reinforces this conclusion.

Achilles uses nature to purify the earth of the Amazons (57.15-17). The horses drown themselves and a storm sinks the fleet-but washes ashore the dead and dying. As a result, "Achilles cleaned the island easily by pulling in

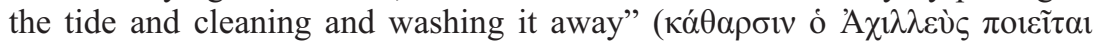

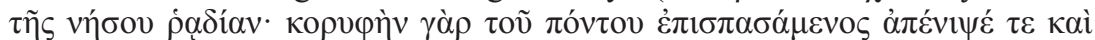
$\dot{\alpha} \pi \varepsilon \dot{\varepsilon} \lambda \nu \sigma \varepsilon \tau \alpha \tilde{v} \tau \alpha, 57.17)$. Achilles uses a force of nature to restore the natural order the Amazons have violated. He drowns the horses, sinks the fleet with a storm, and washes away the detritus with a wave. Achilles three times uses the sea, the force of nature associated with him via his mother, to clean or, perhaps

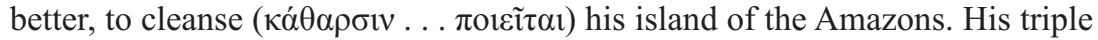
use of this natural force restores the natural domination of Hellenic masculinity and purifies the earth of any trace of feminine independence. In one sense, Achilles is defending Greek lands from foreigners just as he has done before. Yet this story also exposes the patriarchal masculinity integral to his identity. He punishes these women not just for attacking him but as aberrant violations of nature of whom the earth must be purified.

One provocative conclusion may be drawn from the dramatic date of this episode. According to the Vinedresser, "I think it was in the year that Leonidas of

60. See Grossardt 2006, 765 for parallels to Lucian's $V H$ in this passage.

61. See Grossardt 2006, 757-58, 766.

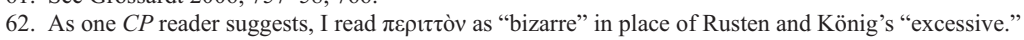


Rhodes won his first race at the Olympic Games that Achilles killed their fierc-

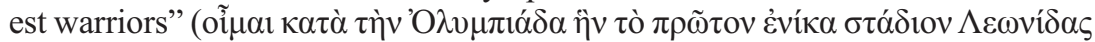

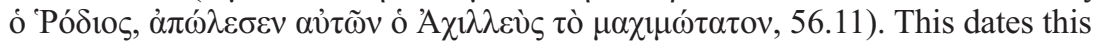
event to circa $164 \mathrm{BCE}$, which is preposterous. An Amazon fleet cruising the Euxine so late - after the Second Punic War! - so assaults the reader's suspension of disbelief as to break it. Had they hidden from Xenophon? ${ }^{63}$ The key to understanding how this episode fits in with the prior two rests in understanding why the text places such an impossibly late date on this invasion.

The strange chronology of this passage has been little discussed. ${ }^{64}$ Peter Grossardt, in his commentary on this passage, has made the only attempt I am aware of to understand its significance. He argues that the Amazons' crime echoes Antiochus' divine punishment - his death in $164 \mathrm{BCE}$ - for his attempted violation of Artemis' shrine. ${ }^{65}$ In turn, this alludes to the assassination of Caracalla near a different shrine in order to condemn it. I find this unsatisfying. While the Amazons' invasion does coincide with Antiochus' crime, it is otherwise awkward. Antiochus must be represented by the Amazons and Artemis by Achilles - neither association is comfortable - and the merchants have no parallel since Antiochus' army escaped punishment. It is also not clear why Philostratus would so obscurely criticize Caracalla's assassination. There is a more fitting explanation for the invasion's chronology.

There are several more conventional ways that Philostratus could have referred to the year $164 \mathrm{BCE}$ : one would be to name it the first year of the 154th Olympiad. Instead he only implies this Olympic year by particular reference to the Olympic games that saw Leonidas' first victory. This is hardly the least convoluted way of identifying the year. His manner of dating draws attention to these particular Olympic games themselves. These Olympics are, quite provocatively in this context, the first held in Roman Greece. As a symbol for Greece's new political situation, what better touchstone than this panhellenic and unifying sporting event's first exposure to Roman dominion?

Although it seemed ridiculous to date the Amazons' invasion to $164 \mathrm{BCE}$, we should realize that this was not the only invasion of Greece at this time. The Third Macedonian War ended in 168 BCE with the dissolution of the Antigonid empire, the first entry of Greece into Rome, and the (partial) reorganization of Thessaly, all in the months after the Olympic games of 168 BCE. ${ }^{66}$ We have seen Achilles fiercely oppose Xerxes, Darius, the Amazons, and the Thessalians to protect Greeks from threats foreign and domestic. The episode of the Trojan slave reveals that Achilles detests Romans. Why, then, were these despised foreigners able to subjugate Greeks? This episode reveals that while

63. From An 4.6.4 to 6.21, Xenophon travels from the Phasis to the Thermodon.

64. Rusten $(2004,147)$ notes the date as bizarre but does not explain it.

65. As Grossardt $(2006,756)$ notes, this can be found at Polyb. 31.9.

66. Miller $(1975,224)$ dates the Olympics of 168 to August nineteenth, although, per Dany $(2000,435$ n. 13), the specific day remains disputed. The settlement of Greece began with the arrival of the senatorial commission in February 167, per Dany $(2000,436)$. Gruen (1982, 257-58) argues that Greeks considered this settlement the beginning of Rome's rule. Graninger $(2011,34-35)$ also points to $167 \mathrm{BCE}$ as the most significant year for the Antigonids' former subjects. 
the Romans were defeating Perseus, Achilles was distracted by the Amazons. Achilles, the panhellenic hero, fails to keep Greece independent of Rome.

Achilles' distraction during the Roman invasion casts more light on the second episode. So many centuries after the Trojan war, Achilles horrifically kills the Trojan slave because she was freshly symbolic of Rome's piecemeal conquest of Greece. Achilles did to her what he could not stop Rome from doing to Greece. Achilles, the savage defender of Greece, fails. He has obtained revenge before- he murders the Trojan prisoners to avenge Patroklos; attacked by Xerxes he aids Alexander-but this time it is different. His treatment of the Trojan slave is not only horrific but pathetic in its impotence.

Finally, in addition to Achilles' hostility toward Rome in general, we may be able to see a more contemporary concern in this passage that focuses on the tension between the role of women in Roman society and their position in Greek myth. Achilles' disgust with powerful women may echo criticisms made of the women of the Severan dynasty, especially following Severus' death. Domna was granted control over Caracalla's correspondence and her relatives were more visible still. ${ }^{67}$ It was alleged that Maesa was central to Macrinus' overthrow, that Sohaemias and Maesa virtually ran Elagabalus' government, and that Mamaea and Maesa controlled Severus Alexander. ${ }^{68}$ Although Ellen Aitken argues that the text's contrast between foreigners like the Amazons and foreigners like the Phoenician "may well serve to highlight attempts by the Phoenician women of the Severan dynasty to present themselves as authentically Greek by engaging in the practices proper to the cult and culture of the Hellenic heroes," I would argue that the Severans may actually be better associated with the Amazons. ${ }^{69}$ So long as these Amazons are dishonorable foreigners living shamefully in the East, Achilles ignores them. It is only when these women come from East to West with their submissive men to impose themselves on Greece that Achilles grows indignant. Achilles, who despises women who dominate men, would hardly be thrilled with the alleged power of the Syrian women of the Severan dynasty. These women were said to dominate their male relatives and, by extension, all Roman men, not unlike the Amazons and their merchants. The Heroikos' story of the Amazons may suggest how this Achilles would treat the Severan dynasty, which often based its legitimacy upon, and was perhaps sometimes guided by, its female members. ${ }^{70}$

Thanks to two different chronological associations, this episode may be interpreted twice. Within the context of the second century BCE, Achilles is revealed to be a virulent misogynist who reviles and destroys powerful women - but only once they threaten him and, through him, Greece. The timing of the episode, virtually simultaneous with the first Roman conquest of Greece, suggests why Achilles, the panhellenist who detests foreigners, failed to defend Greeks as usual. In reference to the political situation of Philostratus'

67. See Levick 2007, 95-96 for Domna's position at Caracalla's court.

68. See Levick 2007, 148-52. On Maesa and Macrinus, see Herodian 5.3.11-12; on Sohaemias and Maesa, see Levick 2007, 149; on Maesa and Mamaea, see Herodian 6.1.1-4.

69. Aitken 2004, 279.

70. Maclean and Aitken (2001, lxv-1xvi) and Aitken (2004, 279-80) discuss other, quite different, attitudes toward women displayed elsewhere in Philostratus' corpus. 
own period, one may also see a potential response to the increased visibility and (rumors of) power of the women of the Severan dynasty. This Achilles, savage toward women who dominate men, especially Eastern women and Greek men, cannot comfortably coexist with the Severans.

\section{CONCLUSION}

I have argued that Philostratus' portrayal of Achilles constitutes an experiment with a mode of Hellenism distinct from the other types of Hellenism depicted in the Herōikos and commonly discussed in other texts of the Second Sophistic. Achilles is fervent in his defense of Greeks and brutal in his treatment of outsiders, whether dangerous foreigners or disloyal Greeks. Achilles' hard-line beliefs and his extreme violence may make the reader wonder: if the Heroikos juxtaposes three sorts of Hellenic lifestyles, should Achilles' be preferred?

The Heroikos has no narrator: Philostratus neither speaks nor appears in the text. ${ }^{71}$ None of the three Hellenisms can be directly endorsed or condemned by Philostratus. I will close this article by arguing that Achilles' lifestyle is ultimately problematized by the demerits that slowly pile up. ${ }^{72}$ First, and perhaps most tellingly, Achilles ruins his ancient friendship with Protesilaos.

Achilles' decision to destroy Thessaly came to the attention of Protesilaos, another Thessalian. Protesilaos, who is unsurprisingly bothered by Achilles' unilateral decision to destroy their homeland, intercedes on behalf of Thessaly. The Vinedresser says that Protesilaos said to him, "At the moment you find me quite estranged from him. I noticed he was enraged at the Thessalians because of the offerings, and said, 'Achilles, please overlook this for my sake.' But

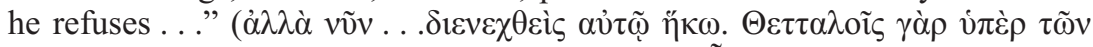

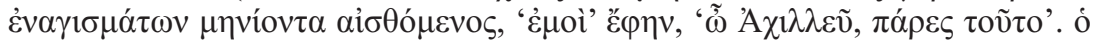
$\delta$ ' ov̉ $\pi \varepsilon i ́ \theta \varepsilon \tau \alpha 1,53.19)$. Although Protesilaos had once been such a close friend of Achilles that he was a constant guest on Leuke, Achilles' treatment of the Thessalians was such that Protesilaos leaves Leuke in disgust (53.18). Achilles' savage behavior ends their millennium-long friendship. In fact, Achilles' relationships all trend in this direction.

Initially, Achilles appears to be both powerful and popular. Not only does he defend Greece from Xerxes and help Alexander defeat Persia but, at Salamis and Troy both, he is the only revenant who is asked to unite Greece into a great army against foreigners. Despite this, his brutality in defense of his narrow Hellenism gradually isolates him from all of his supporters.

The Thessalians (sporadically) sacrificed at his Trojan tomb - until he destroyed them. Protesilaos was a constant companion-until Achilles spoiled their friendship. The merchants who are shipwrecked among the Amazons had previously visited him on Leuke-but he kills them. Achilles develops a friendship with a passing merchant - only to abuse this friendship. Achilles has harmed, alienated, or killed everyone who once visited him. In the end, he

71. See Billault 2000, 41; Kim 2010, 175-77; Hodkinson 2011, esp. 117-18.

72. See Flinterman 1995, 29-51; Maclean and Aitken 2001, xlvii-xlviii; Gruen 2006; and Whitmarsh 2009a for Roman co-option of Greek elites and Greek elite responses to Roman power. 
and Helen are all but abandoned on their desert island. Achilles has nobody to blame but himself: as angry as Homer's Achilles is, he is more sympathetic and far less dangerous than his genuine, monstrous model revealed by the Vinedresser. Achilles' brutal Hellenism imposes epic values upon a modern, unepic world. If this is the authentic Achilles, it is no wonder that Homer's fraud is the popular one.

I close by suggesting that this text uses Achilles to flirt with the idea of resistance to Rome. It is not the only time such an idea is mentioned in Philostratus' corpus, but the idea is developed here to the greatest degree. ${ }^{73}$ This Achilles is a savage xenophobe who may be able to restore Greece to dominance through brutality toward all non-Greeks, but the consequences are equally brutal. Protesilaos, all the Thessalians, Julia Domna and the Severans, surely a Favorinus, surely the Phoenician and perhaps even the Vinedresser would, at best, be excluded from Achilles' Greece. Flirtation with the thought of Greece's freedom from Rome is hardly rare in the Second Sophistic, but the negative repercussions this Achilles experiences show that Greek independence would leave Greece, like Achilles, isolated on a desert island surrounded by the bones of erstwhile friends. The Heröikos' Achilles reveals why Greece cannot free itself from Rome without losing itself in the process. ${ }^{74}$

Kansas State University

73. See Rochette 1997, 75-83 and Whitmarsh 2009a, 119 for other moments of hostility toward Rome in Philostratus and in contemporary literature.

74. I would like to thank Sara Luly, Samuel Flores, Anthony Kaldellis, Stephen Maiullo, and CP's readers for the thought and time they have shared with me on this project.

\section{LITERATURE CITED}

Ahl, Frederick, and Hanna Roisman. 1996. The "Odyssey" Re-Formed. Ithaca, N.Y.

Aitken, Ellen Bradshaw. 2004. Why a Phoenician? A Proposal for the Historical Occasion for the Heroikos. In Aitken and Maclean 2004, 267-84.

Aitken, Ellen B., and Jennifer K. Berenson Maclean, eds. 2004. Philostratus" "Heroikos": Religion and Cultural Identity in the Third Century C.E. Atlanta.

Anderson, Graham. 1986. Philostratus: Biography and Belles Lettres in the Third Century A.D. London.

Asirvatham, Sulochana R. 2008. No Patriotic Fervor for Pella: Aelius Aristides and the Presentation of the Macedonians in the Second Sophistic. Mnemosyne 61: 207-27.

Beschorner, Andreas. 1999. Helden und Heroen, Homer und Caracalla: Übersetzung, Kommentar und Interpretationen zum Heroikos des Flavios Philostratos. Bari.

Betz, Hans Dieter. 2004. Hero Worship and Christian Beliefs: Observations from the History of Religion on Philostratus's Heroikos. In Aitken and Maclean 2004, 25-47.

Billault, Alain. 2000. L'univers de Philostrate. Brussels.

Blok, Josine. 1995. The Early Amazons: Modern and Ancient Perspectives on a Persistent Myth. Leiden.

Blomart, Alain. 2004. Transferring the Cults of Heroes in Ancient Greece: A Political and Religious Act. In Aitken and Maclean 2004, 85-98.

Bradley, Mark. 2009. Colour and Meaning in Ancient Rome. Cambridge. 
Braund, David. 1994. Georgia in Antiquity: A History of Colchis and Transcaucasian Iberia 550 $B C-A D$ 562. Oxford.

Bremmer, Jan M. 2000. The Amazons in the Imagination of the Greeks. AAntHung 40: 51-59.

Bremmer, J. M., and N. M. Horsfall. 1987. Roman Myth and Mythography. BICS 52. London.

Burkert, Walter. 2004. Jason, Hypsipyle, and New Fire at Lemnos: A Study in Myth and Ritual. In Aitken and Maclean 2004, 99-123.

Cantarella, Eva. 1987. Pandora's Daughters: The Role and Status of Women in Greek and Roman Antiquity. Baltimore.

Corcella, Aldo. 2007. Book IV. In A Commentary on Herodotus: Books I-IV, ed. Oswyn Murray and Alfonso Moreno, 543-721. Oxford.

Dany, O. P. 2000. Livy and the Chronology of the Years 168-167. CQ 50: 432-39.

de Lannoy, Ludo. 1977. Flavii Philostrati Heroicus. Leipzig.

Dué, Casey, and Gregory Nagy. 2002. Preliminaries to Philostratus' On Heroes. In Maclean and Aitken 2002, xv-xli.

Edmonds, John. 2000. The Mystery of Imperial Purple Dye. Historic Dyes 7. Little Chalfont.

Erskine, Andrew. 2001. Troy between Greece and Rome: Local Tradition and Imperial Power. New York.

Flinterman, Jaap-Jan. 1995. Power, Paideia and Pythagoreanism: Greek Identity, Conceptions of the Relationship between Philosophers and Monarchs, and Political Ideas in Philostratus' "Life of Apollonius." Amsterdam.

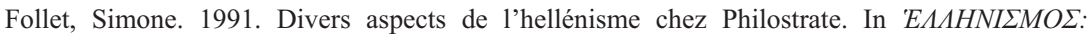
Quelques jalons pour une histoire de l'identité grecque; Actes du Colloque de Strasbourg, 25-27 Octobre 1989, ed. Suzanne Saïd, 205-15. Leiden.

- 2004. Philostratus' Heroikos and the Regions of the Northern Aegean. In Aitken and Maclean 2004, 221-35.

Gleason, Maud. 1995. Making Men: Sophists and Self-Presentation in Ancient Rome. Princeton, N.J.

Graninger, Denver. 2011. Cult and Koinon in Hellenistic Thessaly. Boston.

Grossardt, Peter. 2006. Einführung, Übersetzung und Kommentar zum "Heroikos" von Flavius Philostrat. 2 vols. Basel.

Gruen, Erich S. 1982. Macedonia and the Settlement of 167 B.C. In Philip II, Alexander the Great, and the Macedonian Heritage, ed. Lindsay Adams and Eugene Borza, 257-67. Washington, D.C.

. 1992. Culture and National Identity in Republican Rome. Ithaca, N.Y.

2006. Greeks and Non-Greeks. In The Cambridge Companion to the Hellenistic World, ed. Glenn Bugh, 295-314. Cambridge.

Hodkinson, Owen. 2011. Authority and Tradition in Philostratus" "Heroikos." Satura 8. Lecce.

Hughes, Derek. 2007. Culture and Sacrifice: Ritual Death in Literature and Opera. Cambridge.

Kaldellis, Anthony. 2007. Hellenism in Byzantium: The Transformations of Greek Identity and the Reception of the Classical Tradition. Cambridge.

Kim, Lawrence Y. 2010. Homer between History and Fiction in Imperial Greek Literature. Cambridge.

Levick, Barbara. 2007. Julia Domna, Syrian Empress. London.

Liddle, Aidan. 2003. Arrian: Periplus Ponti Euxini. London.

Maclean, Jennifer K. Berenson. 2004. The aivot of the Heroikos and the Unfolding Transformation of the Phoenician Merchant. In Aitken and Maclean 2004, 251-65.

Maclean, Jennifer K. Berenson, and Ellen Bradshaw Aitken. 2001. Flavius Philostratus: "Heroikos." Atlanta.

. 2002. Flavius Philostratus: "On Heroes.” Atlanta.

Magie, David. 1950. Roman Rule in Asia Minor, to the End of the Third Century after Christ. 2 vols. Princeton, N.J. 
Mestre, Francesca. 2004. Refuting Homer in the Heroikos of Philostratus. In Aitken and Maclean 2004, 127-41.

Miles, Graeme. 2005. Music and Immortality: The Afterlife of Achilles in Philostratus' Heroicus. AncNarr 4: 66-78.

Miller, Stephen. 1975. The Date of Olympic Festivals. MDAI(A) 90: 215-37.

Nagy, Gregory. 2001. The Sign of the Hero: A Prologue. In Maclean and Aitken 2001, x-xxxv.

Ondine Pache, Corinne. 2004. Singing Heroes-The Poetics of Hero Cult in the Heroikos. In Aitken and Maclean 2004, 3-24.

Radet, Georges. 1925. Notes critiques sur l'histoire d'Alexandre. Bordeaux.

Reinhold, Meyer. 1970. History of Purple as a Status Symbol in Antiquity. Brussels.

Richardson, Nicholas. 1993. The "Iliad": A Commentary. Vol. 6, Books 21-24. Cambridge.

Rochette, Bruno. 1997. Le latin dans le monde grec: Recherches sur la diffusion de la langue et des lettres latines dans les provinces hellénophones de l'Empire romain. Brussels.

Rusten, Jeffrey. 2004. Living in the Past: Allusive Narratives and Elusive Authorities in the World of the Heroicus. In Maclean and Aitken 2004, 143-58. Atlanta.

Rusten, Jeffrey, and Jason König. 2014. Philostratus: "Heroicus," "Gymnasticus," "Discourses" 1 and 2. Cambridge, Mass.

Schmitz, Thomas. 1997. Bildung und Macht: Zur sozialen und politischen Funktion der zweiten Sophistik in der griechischen Welt der Kaiserzeit. Munich.

Spawforth, Tony. 2006. 'Macedonian Times': Hellenistic Memories in the Provinces of the Roman Near East. In Greeks on Greekness: Viewing the Greek Past under the Roman Empire, ed. David Konstan and Suzanne Saïd, 1-26. Cambridge.

2012. Greece and the Augustan Cultural Revolution. Cambridge.

Swain, Simon. 1996. Hellenism and Empire: Language, Classicism, and Power in the Greek World AD 50-250. Oxford.

Toll, Katharine. 1997. Making Roman-ness and the Aeneid. ClAnt 16: 34-56.

Wallace-Hadrill, Andrew. 2008. Rome's Cultural Revolution. Cambridge.

Whitmarsh, Tim. 2001. Greek Literature and the Roman Empire: The Politics of Imitation. Oxford. . 2004. The Harvest of Wisdom: Landscape, Description, and Identity in the Heroikos. In Aitken and Maclean 2004, 237-49.

. 2009a. Greece and Rome. In The Oxford Handbook of Hellenic Studies, ed. George BoysStones, Barbara Graziosi, and Phiroze Vasunia, 114-28. Oxford.

- 2009b. Performing Heroics: Language, Landscape and Identity in Philostratus' Heroicus. In Philostratus, ed. Ewen Bowie and Jaś Elsner, 205-29. Cambridge. 